\title{
Does Background Linearity Matter? A Study About Teacher's Professionalism in Early Childhood Education
}

\author{
Putri Aulia Juliyanti ${ }^{1, *}$, Hani Yulindrasari ${ }^{2}$ \\ ${ }^{1,2}$ School of Postgraduate Studies, Universitas Pendidikan Indonesia, Bandung, Indonesia \\ ${ }^{*}$ Corresponding author. Email: putriaulia@upi.edu
}

\begin{abstract}
Teachers' academic qualification is supposed to correlate with a person's skill in a particular area. Thus, in many countries academic qualification has become a significant marker of professionalism. In Indonesia, the teacher's professionalization scheme has emphasised academic linearity in every level of schooling including early childhood education (ECE). ECE, which is specifically different from other levels of schooling, requires other qualities (such as caring, nurturance, and patience) in addition to academic competence. In reality, ECE teachers' in Indonesia have various educational backgrounds which are not necessarily linear with the field of early childhood education. Some research shows that ECE teachers' teaching performance is not related to the linearity of their academic background. Based on literature review, this paper will examine what has been understood about ECE teacher professionalism and its relation to academic linearity. The study concludes that the quality of early childhood learning in kindergarten is influenced largely by factors of the teacher's educational linearity.
\end{abstract}

Keywords: Linearity, professionalism, early childhood education.

\section{INTRODUCTION}

Teacher professionalism in the scope of early childhood education is an important thing to be able to produce good and quality output, because early childhood is a place where basic knowledge and skills are anchored for future generations. States that the demand for quality service delivery is becoming increasingly heavy in the world of education [1]. Professional teachers will be able to direct the educational goals of building the young generation into a hopeful nation generation [2]. Several opinions provide clarity that the task of teacher professionalism is related to the need to have adequate knowledge in accordance with their field of work because of the skills needed to support the learning process as well as some of the required attitude and personality characteristics.

Linearity has a huge influence on the success of student achievement [3]. In the field of education, especially early childhood education, demands for the ability to provide more professional services have an increasingly important meaning [4], meaning that with the diversity of characteristics possessed by different children, the knowledge and skills of teachers are needed to understand and guiding early childhood so that they can grow and develop properly. Early childhood educators are expected to be able to reach all knowledge about early childhood development both in terms of their needs and characteristics of the child, besides that teachers must have the qualifications, competence, and dedication in the realm of early childhood education to carry-out their duties as an educator. A teacher who is said to be linear in academic qualifications must have a broad insight into the stages of child development so that he is said to be a professional in applying his knowledge to early childhood.

But unfortunately, in Indonesia there are still many educators who have non-linear academic qualifications or do not have an early childhood education background. This paper will discuss whether academic linearity is important in the practice of early childhood education and whether linearity determines professionalism? This paper is written based on an analysis of the existing literature and research on teacher educational backgrounds and their competence, performance and professionalism. 


\subsection{Teacher's Professionalism in Early Childhood Education}

Teacher professionalism is closely related to the ability to realize and actualize the competencies required for every teacher [1]. Professional itself comes from the word profession which is defined as a job that requires further education in science and technology which is used as a basic tool to be implemented in various useful activities [5]. Teacher professionalism demands that it continues to develop in accordance with developments in science, technology and the needs of society. Teachers are key to improving the quality of education, and they are at the center of any educational reform effort aimed at change. The teacher's role cannot be replaced by anything because in cultivating the attitudes and personalities of students, it is the teacher who applies them directly. The professionalism of early childhood educators can be seen from their academic qualifications and teaching experience. If the academic qualifications of an early childhood educator have met the requirements and standards of early childhood education, then they will have the appropriate competencies and are needed in managing early childhood learning [6].

\subsection{Linearity}

Teacher qualification can be viewed as a job that requires qualified abilities. In the field of education, linear is the conformity between the diploma or department taken with the subjects being taught according to what the teacher teaches at the school or place of teaching [7]. Linear teachers are generally more competent so that these more competent teachers are in fact more professional in carrying out their duties to become teachers [8]. Linearity has a huge influence on the success of student achievement [3]. The quality of early childhood learning at the Kindergarten level is largely determined by the performance of the educators themselves. PAUD teachers must have a PAUD certificate as a higher education institution and program that prepares PAUD teachers who are significant in improving early childhood education, then have professional teacher skills, responsibility for roles and functions as educators and have characteristics as PAUD teachers [9]. The government itself is of course very concerned with linearity because it is to improve the quality of education and invite teachers to rise up and be motivated to become learner by pursuing the required qualifications

\section{BACKGROUND}

\subsection{The Importance of educators}

Quality educators must have a strong commitment and sufficient competence to create a situation that encourages initiative and passion and responsibility for lifelong learning. The availability of qualified teaching staff and teachers is one thing that needs to get attention and also the spotlight [10]. Within the scope of early childhood, where children are in the golden age, of course, they need a qualified educator to meet the needs of children with different characteristics. A quality teacher certainly understands, understands and masters the curriculum, learning methods, and the stages of child development. Hisrich Peters $(2013,13)$ in [10] suggests that a teacher's educational background is a foundation in carrying out a professional activity.

The problem of teacher professionalism is not only measured through teacher standard tests, in an article written by [11] says that in terms of work culture, which means the level of teacher professionalism measured through work culture will increase accountability so that it is sustainable in the application of teacher standards . The development of teacher professionalism is a key process in the broader agenda to raise standards and increase the capacity for community growth by improving policy practice in the sphere of education [12]. One of these policies is regarding the linearity of the diploma, the aim of which is to increase the professionalism of educators in each institution. With this kind of process a nation and state can pass on religious values, culture, thoughts, and expertise to the next generation so that they are truly ready to face the future in a brighter life [13].

\subsection{Teacher Competence}

There is also another research written by Dale [14] that talking about the teaching profession means teaching is a profession, even when we cannot mark the core characteristics. The attempt to acquire the characteristics associated with the profession is usually called professionalization, a job strategy which is sometimes called a professional project. Several aspects of the teacher professional project appear to be working. However, in today's industrial society, most professionals are directly employed and regulated by the state. As points out, some professions have a form of licensed autonomy, while others have regulated autonomy [15]. For teachers themselves, this involves a clearer specification of what they are expected to achieve, rather than leaving it to professional judgment. However, it is not entirely true that, as Neave implied, states thus ignore any interest in how they achieve these things.

Hoyle uses the term professionalism to refer to the strategies and rhetoric used by members of a job in an attempt to improve status, salary and circumstances. However, he uses the term professionalism to refer to the knowledge, skills, and procedures used by teachers in the teaching process. Now there is not only a struggle for professionalism in the conventional sense, but also a struggle for professionalism. The state has taken a proactive part in this, both positively (in the sense of what 
it consists of) and negatively (in terms of what should be prevented if not prohibited). Indeed, [16] argues that in England, during the so-called golden age of teacher control from 1944 to the mid-1970s, parents of children in public schools were expected to trust professionals and accept that teachers know what is required best for their children. The state does not appear to want to intervene, even though it is effectively paying teacher salaries.

\subsection{The Importance of Linearity}

It was also said from the research conducted by Saroni [17] that the State of Indonesia itself has been enforced some time ago, this has become a concern and a problem for teachers who already have a diploma but are not in accordance with the subject being taught due to the adjustment of teaching material with Academic qualifications and diplomas are the standard measures of material ability being handled [17] Therefore, a policy regarding linearity was born that aims to increase the professionalism of teachers and teaching staff in educational institutions. Teachers in the education and learning process are those who have educational qualification backgrounds and of course they are the ones who have the feasibility of teaching according to their respective professions [18]. Linearity actually wants to make human resources in Indonesia as users or experts in a particular field. As is the case with early childhood educators where the goal of teaching with children who are still in their golden age means that the provision of educational services to children must be in accordance with the provisions so that the developmental aspects of each child can be achieved optimal.

\section{CONCLUSION}

The professionalism of an early childhood educator can be seen from the academic qualifications and teaching performance of the teacher. Professionalism is also used for matters that refer to knowledge of skills and procedures used by teachers in the teaching process. Linearity itself is a very important thing and should be owned by every teacher in order to make student output more competent because the insights and knowledge possessed by the teacher are more focused on the field of study they are working on. PAUD teachers must have a PAUD certificate as a higher education institution and program that prepares PAUD teachers who are significant in improving early childhood education. This is a necessity and a demand that currently early childhood educators must have academic qualifications in accordance with their field of work. In addition, the term professionalism can also be shown to members of a job who use strategy and rhetoric in an effort to improve salary status and conditions.

\section{REFERENCES}

[1] Sutarmanto. Kompetensi dan profesioanalisme guru pendidikan anak usia dini. Jurnal Visi Ilmu Pendidikan. 2009;1(1):16-31. Available from: http://dx.doi.org/10.26418/jvip.v1i1.42.

[2] Alma, B. Guru Profesional Menguasai Metode dan Terampil Mengajar. Bandung: Alfabeta; 2009.

[3] Diksa AO, Aufa M. Studi evaluasi kinerja guru kelas mi bersertifikasi ijazah non-pgmi terhadap kompetensi pedagogik dan profesional di kabupaten magelang. Pendas: Jurnal Ilmiah Pendidikan Dasar. 2018;3(1):110-22.

[4] Marienda W, Zainuddin M, Hidayat EN. Kompetensi dan profesionalisme guru pendidikan anak usia dini. Prosiding Penelitian dan Pengabdian kepada Masyarakat. 2015;2(2):147-56.

[5] Nurdin S, Usman MB. Guru profesional \& implementasi kurikulum. Ciputat Pers; 2002.

[6] Suryana D. Profesionalisme guru pendidikan anak usia dini berbasis peraturan menteri no. 58 tahun 2009. Pedagogi: Jurnal Ilmiah Ilmu Pendidikan. 2013;13(2):53-61.

[7] Adi HC, Zulvia M, Asyha AF. Studi kompetensi guru dan linieritas pendidikan dalam peningkatan prestasi belajar siswa di SD Negeri 1 Gunung Tiga dan SD Negeri 1 Ngarip Lampung. Al-Tadzkiyyah: Jurnal Pendidikan Islam. 2019;10(2):245-55. Available from: https://doi.org/10.24042/ atjpi.v10i2.5140.

[8] Lubis AA, Pulungan MY, Siregar LY. Pengaruh kualifikasi pendidik dan penerapan belajar sambil bermain terhadap kreatifitas pada anak usia anak dini di taman kanak-kanak se-kota Padangsidimpuan. Tazkir: Jurnal Penelitian Ilmu-ilmu Sosial dan Keislaman. 2016;2(2):143-56.

[9] Taran EG. Pengaruh latar belakang pendidikan dan motivasi terhadap kompetensi profesional guru (Studi kausal terhadap guru TK Se-Kecamatan Langke Rembong Kabupaten Manggarai NTT). JIPD (Jurnal Inovasi Pendidikan Dasar). 2019;3(1):16-24.

[10] Sachs J. Teacher professionalism: Why are we still talking about it? Teachers and teaching. 2016;22(4):413-25. Available from: 10.1080/ 13540602.2015.1082732.

[11]Evans L. Profesionalisme, profesionalitas dan pengembangan pendidikan profesional. Jurnal Studi Pendidikan Inggris. 2008;56(1):20-38.

[12] Nurkholis N. Pendidikan dalam upaya memajukan teknologi. Jurnal kependidikan. 2013;1(1):24-44.

[13]Disas EP. Analisis kebijakan pendidikan mengenai pengembangan dan peningkatan profesi guru. Jurnal Penelitian Pendidikan. 2017;17(2):158-166 
Available from: https://ejournal. upi.edu/index.php/ JER/article/view/8251/5184.

[14]Dale R. Kebijakan negara bagian dan pendidikan. Open University Press; 1989.

[15] Suharto E. Kebijakan sosial. Bandung: Alfabeta. 2011.

[16]Masruri A. Linieritas ijazah (Sebuah analisis kebijakan pendidikan). Andragogi: Jurnal Pendidikan Islam dan Manajemen Pendidikan Islam. 2019;1(2):242-53.

[17] Saroni M. Personal branding guru: Meningkatkan kualitas dan profesionalitas guru. Yogjakarta: ArRuzz Media. 2011. 